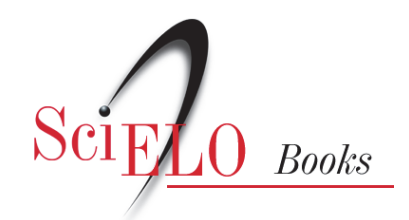

\title{
Capítulo III \\ Uma nova ciência para um novo senso comum
}

\author{
Marcelo Gomes Germano
}

GERMANO, MG. Uma nova ciência para um novo senso comum [online]. Campina Grande: EDUEPB, 2011. 400 p. ISBN 978-85-7879-072-1. Available from SciELO Books $<$ http://books.scielo.org $>$.

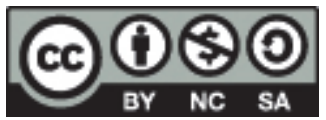

All the contents of this work, except where otherwise noted, is licensed under a Creative Commons Attribution-Non Commercial-ShareAlike 3.0 Unported.

Todo o conteúdo deste trabalho, exceto quando houver ressalva, é publicado sob a licença Creative Commons Atribuição Uso Não Comercial - Partilha nos Mesmos Termos 3.0 Não adaptada.

Todo el contenido de esta obra, excepto donde se indique lo contrario, está bajo licencia de la licencia Creative Commons Reconocimento-NoComercial-CompartirIgual 3.0 Unported. 


\title{
Capítulo III
}

\section{Uma nova ciência para um novo senso comum}

\author{
"A utopia é, assim, o realismo desesperado \\ de uma espera que se permite lutar \\ pelo conteúdo da espera..." \\ (Boaventura Santos).
}

\section{Uma nova ciência como utopia necessária}

No contexto de uma ciência cada dia mais ousada em suas inovações tecnológicas, que parece seguir uma marcha inexorável e imune a qualquer obstaculização de natureza crítica, não é tarefa simples defender a tese da emergência possível e necessária de uma nova ciência. Uma ciência que, além de outras características peculiares, pretenda-se comunicativa e popular.

Felizmente não estamos construindo uma trilha solitária, mas um percurso compartilhado por outros importantes desbravadores que, não obstante diferentes orientações teóricas reconhecem, na confluência de algumas crises, se não o prenúncio, pelo menos a possibilidade e necessidade de um novo paradigma ${ }^{39}$ científico. A título

39 Embora não se trate de um novo modelo universal que possa abrigar-se nos limites de um outro paradigma, usaremos a terminologia kuhniana, mas apenas no sentido da novidade revolucionária. Em outros momentos, usaremos o termo uma nova ciência, no sentido de apontar o caráter inovador de algumas novas teorias e concepções que se desenvolveram ao longo do século XX. 
de exemplo, poderíamos citar, entre muitos outros, os nomes de Prigogine (1996, 1993); Prigogine e Stengers (1997); Maturana e Varella (2002); Vandana Shiva (2001); Hugh Lacey (2004b, 2007b); Edgar Morin (2003); Jurgen Habermas $(1983,1997)$ e Boaventura Santos $(2000,2003$, 2004a ,2004b, 2005,).

Um fato muito curioso e que servirá para ilustrar a nossa discussão neste capítulo é a constatação de que as duas mais importantes revoluções e crises no contexto da física clássica, a teoria da relatividade e a mecânica quântica, firmaram-se como novidades científicas em torno do reconhecimento de algumas impossibilidades. No caso da teoria da relatividade, a impossibilidade de estabelecer comunicação desprezando os limites da velocidade da luz, e na mecânica quântica, o reconhecimento da impossibilidade de medir, simultaneamente, a posição e o momento de um elétron.

Curiosamente, o conceito de entropia também se fundamenta no reconhecimento de uma impossibilidade que demarca os limites de nosso poder de apreensão da realidade. Neste caso, conforme reconhece Prigogine (1993), a entropia seria o conceito-chave pelo qual o segundo princípio se ligaria às duas outras revoluções anteriormente mencionadas.

Como veremos a seguir, o segundo princípio da termodinâmica nos remete ao conceito de irreversibilidade temporal, com uma consequente quebra de simetria temporal, e o abandono das condições iniciais, além da introdução de espontaneidades no universo da física. De acordo com Prigogine (1993), essa evolução impõe limites 
ao nosso poder de manipulação em dois campos: ela nos fornece um local de atividade no seio da natureza e nos retira da posição de sobrevoo à qual a física clássica nos havia relegado.

Conforme já discutimos no capítulo anterior, foi no contexto da termodinâmica que surgiu um dos primeiros e mais importantes impasses no caminho do projeto universal e determinístico da ciência moderna. É também a partir desta crise que mais tarde se estabelecerá uma das principais e mais inovadoras características da nova ciência: o fim das certezas e da onipotência e o estabelecimento de uma nova aliança entre a história dos homens, seus saberes e sua ciência.

A questão não é nova, mas a resposta construída, a partir das pesquisas em termodinâmica não-linear em seu encontro com a biologia molecular, aponta para um caminho muito diferente daquele que fora construído a partir da ciência moderna. Estamos nos referindo ao antigo dilema do determinismo que, de acordo com Prigogine (1996), só encontrará uma solução satisfatória no encontro com o tempo, dimensão fundamental da existência humana.

Se somos parte da natureza e cada evento é sempre causado por um outro que o antecede, é possível que a vida humana seja completamente governada por leis naturais. Se por um lado nos parece seguro e confortável a existência de uma ordem superior e natural governando tudo, por outro, também nos afigura incômoda a ideia de sermos completamente determinados, previsíveis e sem nenhuma liberdade. Gostamos de reconhecer o nosso livre arbítrio e a nossa capacidade criativa diante do mundo. 
Mas é justamente esse impulso criativo que se desenvolve fascinado pela regularidade e a quase inacreditável possibilidade de poder compreender e planejar o futuro. A coisa mais incompreensível sobre o universo, como havia reconhecido Einstein, é que ele é passível de compreensão.

Em outras palavras, o futuro é determinado ou está em perpétua construção? Qual o verdadeiro lugar de nossa liberdade e do nosso livre arbítrio? É este o dilema do determinismo que, conforme Prigogine (1996) aparece como um desafio a nossa relação com o mundo e com o tempo.

Caso se acredite, como nos lembra Hawking (1988), que o universo não é arbitrário, mas governado por "leis" bem definidas, e se de fato há uma teoria completa e unificada, ela certamente determinará as nossas ações. Se as leis físicas não tinham a pretensão de negar o devir em nome da verdade do ser, ao procurar descrever a mudança, os movimentos caracterizados por velocidades ao longo do tempo, seus enunciados acabaram constituindo o triunfo do ser sobre o devir (PRIGOGINE, 1996).

Ao estabelecer para a lei de queda dos corpos uma dependência temporal e não espacial, Galileu introduziu definitivamente o tempo como quantidade física reversível e fundamental ao estudo dos movimentos. Diferente do que pensava Aristóteles, acreditava que o tempo era contínuo, com infinitos instantes, podendo ser representado por intermédio de um segmento de reta.

Portanto, a mecânica clássica já nasce como uma teoria determinista e reversível temporalmente, ou seja, se levarmos $\mathrm{t} \rightarrow$-t, a segunda lei de Newton $F=m d^{2} x / d t^{2}$, assim como a primeira, a terceira e a lei de Gravitação universal 
$F=G m_{1} m_{2} / r^{2}$, permanecem invariantes (MARTINS 2007). E, embora a mecânica quântica e a teoria da relatividade a tenha revolucionado em muitos aspectos, sua simetria e seu determinismo não foram suficientemente abalados.

Levado às últimas consequências, esse pensamento vai de encontro ao livre arbítrio, à criatividade e à responsabilidade do homem perante seus atos. A esse respeito, Einstein tinha uma visão especialmente clara.

Se a Lua, enquanto efetua o seu eterno curso ao redor da Terra, fosse dotada de consciência de si mesma, estaria profundamente convencida de que se move por sua própria vontade, em função de uma decisão tomada de uma vez por todas. Da mesma forma, um ser dotado de uma percepção superior e de uma inteligência mais perfeita, ao olhar o homem e suas obras, sorriria da ilusão que esse homem tem de agir segundo a sua própria vontade livre (apud PRIGOGINE, 1996, p.20).

Como se percebe, Einstein assume uma posição radical que, de seu ponto de vista, era a única compatível com os ensinamentos da ciência. Contudo, convenhamos, esta não é uma propositura simples de aceitar, e neste particular, temos que concordar com Popper quando afirma:

Considero o determinismo laplaciano, confirmado como parece estar, pelo determinismo das teorias físicas e pelo brilhante sucesso delas - o obstáculo mais sólido e mais sério no caminho de uma explicação e de uma apologia da liberdade, da criatividade e da responsabilidade humanas (apud PRIGOGINE, 1996, p.21). 
De acordo com Popper, o determinismo torna impossível o encontro do homem com a realidade e só no tempo e na mudança encontraremos o fundamento essencial do realismo. A existência do tempo, conforme pergunta Bergson (1984), não provaria que há certa indeterminação nas coisas? Como uma teoria reversível e determinista pode, então, acomodar o indeterminismo associado à irreversibilidade do tempo? Na realidade, esta é uma questão aberta, em que o debate parece estar apenas começando.

Conforme já observamos, a própria física não se constitui nem nunca se constituiu em uma ciência monolítica e já, no século XIX, podemos verificar duas correntes bastante adversas a esse respeito. A primeira representada pela mecânica newtoniana, como protagonista de um universo estático e determinístico, e a segunda pela termodinâmica, oferecendo uma descrição evolutiva, associada à entropia e à irreversibilidade ${ }^{40}$.

Se, conforme acredita Prigogine (1996), o crescimento da entropia designa a direção do futuro, quer no nível de um sistema local, quer no nível do universo como um todo, contrariando a mecânica newtoniana, o tempo que nasce do seio da Termodinâmica é mais próximo do tempo concebido pelo devenir heracliano e pela acepção do senso comum. No entanto, como sugere Bem-Dov (1996), o tempo da irreversibilidade termodinâmica não é mais otimista que o da mecânica de Newton e aponta para o caminho da degenerescência e destruição na qual a ordem e a informação desaparecem progressivamente e o universo tende a um estado homogêneo de equilíbrio e morte.

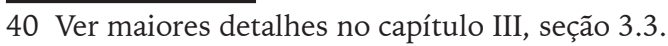


Se por um lado, a mecânica, com suas leis deterministas, não permite qualquer novidade ou futuro surpreendente, a termodinâmica dos sistemas em equilíbrio, embora sugira a permanente possibilidade do novo, conduz a um resultado de fundo metafísico, postulando um fatal e inexorável caminho rumo ao equilíbrio que, seguramente poderíamos assemelhar à eternidade do Ser parmenidiano. No entanto, novas descobertas no universo da própria física apontam na direção de uma perspectiva diferente, em que a irreversibilidade não pode mais ser associada apenas a um aumento da desordem.

De acordo com Prigogine (1996), os desenvolvimentos recentes da física e da química do não-equilíbrio demonstram que a seta do tempo pode ser uma fonte de ordem. Um exemplo simples são as moléculas de hidrogênio e de nitrogênio que, dentro de uma caixa fechada, evoluirão para uma mistura uniforme. Mas ao aquecermos uma das partes da caixa, mantendo a outra mais fria, o sistema evolui para um estado estacionário onde as moléculas de hidrogênio concentram-se mais na parte quente e o nitrogênio na parte mais fria. A entropia produzida pelo fluxo de calor, um fenômeno irreversível, destrói a homogeneidade da mistura e gera ordem em um processo que seria impossível sem o fluxo de calor. A irreversibilidade conduz, ao mesmo tempo, à ordem e à desordem.

... é graças aos processos irreversíveis, associados à flecha do tempo que a natureza realiza suas estruturas mais delicadas e mais complexas. A vida só é possível num universo longe do equilíbrio. O desenvolvimento notável da física e da química de não-equilíbrio nestas últimas décadas reforça, portanto, as 
conclusões apresentadas em A nova aliança:

1. Os processos irreversíveis (associados à flecha do tempo) são tão reais quanto os processos descritos pelas leis tradicionais da física; não podem ser interpretados como aproximações das leis fundamentais. 2. Os processos irreversíveis desempenham um papel construtivo na natureza. 3. A irreversibilidade exige uma extensão da dinâmica (PRIGOGINE, 1996, p. 30).

Seria então a seta do tempo resultado de algum processo mais elementar da natureza? A física de partículas elementares parece dizer que sim. Ao menos é o que indica o estudo de um tipo de méson criado em colisões nucleares, chamado Káon. O Káon neutro, $K^{0}$, transforma-se espontaneamente na sua antipartícula $\mathrm{K}^{-0}$ e vice-versa. Contudo, embora a transformação káon/anti-káon seja simétrica, na transformação antikáon-káon, o káon permanece mais tempo como anti-káon do que como káon. Essa assimetria sugere a existência de uma seta do tempo presente no mundo das partículas elementares (MARTINS, 2007).

No entender de Prigogine (1996), ao longo das últimas décadas do século XX, observa-se o nascimento de uma nova ciência: a física dos processos de não equilíbrio. Essa nova ciência inaugura novos conceitos, tais como: o conceito de auto-organização e as estruturas dissipativas, muito importante para os novos estudos nas áreas de cosmologia, ecologia, química, ciências biológicas e ciências sociais.

Conforme o químico belga, ao estudar os processos dissipativos caracterizados por um tempo unidirecional, a nova física de não equilíbrio confere um novo significado 
à irreversibilidade e esta nova forma de ver as coisas, considerando uma flecha do tempo, propicia o entendimento da ordem biológica orientada para uma complexidade cada vez maior e para a possibilidade de inovações que recupera um traço fundamental da natureza humana, tornando-o extensivo a toda a natureza: a criatividade. Com efeito, no contexto de uma termodinâmica não-linear e de não-equilíbrio, são aceitáveis os fenômenos de auto-organização e associações intercelulares que resultam na formação de organismos mais complexos. "Sem a coerência dos processos irreversíveis de não equilíbrio, o aparecimento da vida na Terra seria inconcebível" (PRIGOGINE, 1996, p.12).

Mesmo no que diz respeito ao modelo cosmológico padrão que estabelece o big bang como resposta para o nascimento do tempo, Prigogine apresenta uma visão distinta e coerente com sua defesa da irreversibilidade temporal. Para o autor, o tempo precede a criação do universo e o big bang, além de não ser uma singularidade, não significa o começo do tempo, mas apenas instabilidade e mudança de fase em um processo que se desenvolve em escala maior. O universo, tal como nós o concebemos atualmente é, na verdade, o resultado de uma transformação irreversível e provém de um outro estado físico. Se o universo tem uma idade, o meio, cuja instabilidade produziu este universo, não a teria.

Em "Uma nova Aliança”, Prigogine (1997) revela sua inquietação mediante duas afirmações profundas e distintas: a do bioquímico Jacques Monod e a do filósofo Henri Bergson. O primeiro ao constatar que "a velha aliança rompeu-se; o homem sabe finalmente que está só na imensidão 
indiferente do universo de que emergiu por acaso"; e o segundo ao reconhecer que "o tempo é invenção ou não é absolutamente nada".

O Universo dura. Quanto mais nos aprofundarmos sobre a natureza do tempo, melhor compreenderemos que duração significa invenção, criação de formas, elaboração contínua do absolutamente novo (BERGSON, apud PRIGOGINE, 1997 p.15).

A nova ciência anunciada por Prigogine, com a qual queremos compartilhar, é uma ciência que não fala mais de um homem solitário em um universo que lhe é estranho, e sim de uma nova e eterna aliança do homem com a natureza que ele descreve. O futuro não é dado, mas está em perpétua construção, e é nesse permanente devenir que encontramos lugar para nossa liberdade. Embora careçamos de leis que nos permitam marchar com segurança, é no caos e na incerteza que encontramos a possibilidade da criação, da novidade e da vida.

Com efeito, embora o projeto reducionista, unificador, universal e determinístico tenha possibilitado os reconhecidos feitos da ciência moderna, também interditou muitas outras formas de apreensão da realidade e, levado às últimas consequências, acabou por inviabilizar o encontro do homem com a realidade, isolando-o do universo no qual, estranhamente teria surgido.

Este programa a quem Bastos Filho (2005) denominou de reducionista unificador, revelou-se insuficiente para dar conta de muitos aspectos de uma realidade cada vez mais 
reconhecida pela sua inerente complexidade ${ }^{41}$. A ciência emergente reconhece as limitações de tal projeto e a sua inevitável superação. Se, enquanto método, o reducionismo pode ser útil, a sua generalização epistemológica é nociva e incompatível com as características da nova ciência. O ambicioso projeto de Galileu e Kepler, que pretendia abandonar as qualidades secundárias, reduzindo-as direta e absolutamente a qualidades primárias, revelou-se inadequado principalmente porque existe uma essencial irredutibilidade das qualidades secundárias às qualidades primárias.

O pensamento científico emergente não defende mais a tese de que, com base em princípios elementares, seja possível avançar para níveis superiores reconstruindo a realidade a partir de elementos básicos. De acordo com Philip Anderson, por exemplo:

A hipótese reducionista não implica de maneira alguma na tese construcionista; a capacidade para reduzir tudo a simples leis fundamentais não implica na capacidade de partir dessas leis e reconstruir o universo. De fato, tanto mais os físicos de partículas nos falam sobre a natureza das leis fundamentais, menos relevância elas parecem ter para os problemas reais do resto da ciência e muito menos ainda para aqueles da sociedade (apud BASTOS FILHO, 2005, p.73).

41 Numa das mais importantes e influentes obras que tratam da emergência dos estudos sobre a complexidade, Lewin descrevia-a como uma "ciência emergente" relacionada aos fenômenos da "vida à beira do caos". Uma década depois, num outro tratamento geral do tema da complexidade, Taylor a define como um fenômeno transversal às ciências, às humanidades, às artes, à religião e à educação, associando-a a "aceleração da mudança" no mundo pós-Guerra Fria e ao surgimento de uma "cultura de rede” (NUNES, 2004). 
Se, desde certo período da aventura histórica do conhecimento humano, tornou-se possível reduzir toda a realidade a simples leis fundamentais, isto não significa que, a partir dessas leis o universo possa ser reconstruído. Se, a partir da formulação de frases e palavras tornou-se possível a elaboração da simbologia elementar das letras, isto não significa que a partir destas seja possível reconstruir as palavras e as frases, os textos e os poemas. Na realidade, palavras e poemas são mais que letras, assim como o universo é muito mais que simples partículas e campos.

Embora alguns simpatizantes do discurso científico tentem se utilizar de alguns conhecimentos da mecânica quântica e da física de partículas elementares para justificar misteriosas influências verificadas em nível macroscópico, o fato é que as descobertas nos domínios das partículas elementares, reconhecidamente o nível mais fundamental de toda a ciência, são quase que completamente estranhas ao universo macroscópico que envolve as questões cotidianas e de senso comum.

Para Atlan (1993), é um erro considerar influências da mecânica quântica em outros domínios, porque o nível em que estão situadas estas experiências é subatômico e não tem nada em comum com o da matéria macroscópica. Ao descobrirmos uma complementaridade entre ondas e corpúsculos nos domínios da mecânica quântica, podemos considerar todas as consequências filosóficas deste modelo, mas sem tirá-lo do seu contexto.

Não existe um elo trivial entre esses dois mundos reconhecidamente relacionados. E, conforme reconhece Bastos Filho (2005, p.73), há, de fato, uma 'cesura' e uma 
descontinuidade entre cada um dos níveis de conhecimento, de modo que, o mais detalhado e extensivamente abrangente do nível mais baixo não contribui de maneira relevante para o conhecimento em níveis mais altos. Embora haja uma reconhecida relação, há também uma estranha e paradoxal incomensurabilidade entre os diversos níveis de conhecimento.

A nova ciência estabelece um claro recorte com o paradigma anterior, desferindo um duro golpe no projeto reducionista unificador que melhor se expressa na conclusão a que chega Bastos Filho.

Esses resultados têm uma grande importância, pois eles revelam que as mudanças qualitativas ocorrendo nesse nível mais alto de descrição nada têm a ver com os detalhes que têm lugar em níveis mais baixos. Em outras palavras, isso significa que essas qualidades do nível mais alto são emergências reais nesse nível e não conseqüências eventuais de detalhes em nível mais baixo. Trata-se de uma estupenda limitação do ideal reducionista unificador (2005, p.75).

De certa forma, reencontramos a tese de Prigogine quando se refere aos processos criativos somente possíveis no contexto da irreversibilidade temporal. As emergências reais e próprias de cada nível não são determinadas a partir de certas configurações descritas em níveis mais elementares, mas constituem emergências originais, únicas e fortemente vinculadas ao seu próprio contexto. 
Embora importantes nomes da comunidade científica ainda se posicionem contra o emergentismo e defendam a antiga tese do construcionismo e de uma teoria final que permitiria uma explicação completa de tudo, a maioria dos físicos brasileiros parece não compartilhar mais dessa ideia.

Em recente pesquisa acerca desse assunto, Zylbersztajn (2003) reuniu a opinião de 152 físicos ligados à Sociedade Brasileira de Física (SBF). Confrontados com sete pequenos textos relacionados aos problemas do construcionismo, emergentismo e teoria final, os entrevistados poderiam emitir os seguintes pareceres seguidos de livres comentários: muito de acordo, de acordo, indiferente, em desacordo, muito em desacordo.

Conforme os resultados dessa pesquisa de Zylbersztajn (2003), analisada em maiores detalhes por Bastos Filho (2005), a grande maioria dos entrevistados rejeitou o ponto de vista construcionista, revelando uma tendência majoritária contrária ao projeto reducionista unificador até então protagonizado pela ciência moderna. Em certa medida, podemos afirmar que a ciência emergente já encontra lugar na comunidade científica brasileira e os resultados do estudo de Zylbersztajn confirmam certa tendência para uma nova visão, mais próxima desse novo paradigma científico. Tal posicionamento não é algo absolutamente dado ou deterministicamente garantido, podendo ser identificado através de algumas características a serem reforçadas e construídas ao longo da história. Se, por um lado, esse novo paradigma pode ser identificado a partir dos sinais produzidos no interior das crises enfrentadas pelo modelo vigente, por outro, não é diretamente determinado por ele. 
Embora o projeto reducionista unificador, sugerido por Galileu e aperfeiçoado ao longo de todo o desenvolvimento posterior da mecânica, tenha sido de inestimável importância para a consolidação da ciência moderna, a redução de todas as qualidades ligadas aos sentidos (qualidades secundárias) às qualidades primárias que, na realidade, se traduzem em quantidades matemáticas, representou e ainda representa uma enorme lacuna no processo de compreensão profunda da realidade. É necessário reconhecer que a ciência moderna produz conhecimentos e desconhecimentos e as especialidades estão muito próximas da ignorância. A esse respeito, é muito oportuna a citação de Burtt referindo-se ao advento vitorioso da ciência moderna.

O Universo gloriosamente romântico de Dante e Milton, que não impunha limites à imaginação do homem, à medida que brincava no espaço e no tempo, fora varrido. O espaço estava identificado ao reino da geometria, o tempo à continuidade do número. $\mathrm{O}$ mundo em que a gente havia imaginado viver, - um mundo rico de cores e sons, perfumado, cheio de alegria, de amor, de beleza, falando em toda parte de harmonia intencional e ideais criadores - achava-se, por fim, apinhado em diminutos cantos dos cérebros de seres orgânicos disseminados. O mundo exterior, realmente, era um mundo frio, duro, sem cores, silencioso, morto, um mundo de quantidade, um mundo de movimento matematicamente calculável em regularidade mecânica. O mundo de qualidades imediatamente percebido pelo homem tornou-se um efeito curioso e muito menos importante da máquina infinita posta além (apud BASTOS FILHO, p. 82). 
A nova ciência, embora reconheça a importância e o alcance das explicações obtidas através das abstrações permitidas pela linguagem matemática, compreende que nem todos os aspectos da realidade podem ser reduzidos aos limites de uma única linguagem. De fato, como reconhece Floriani (2000), cada gênero de pensamento, inclusive o pensamento matemático, é apenas uma abstração incapaz de abarcar a realidade em sua totalidade. O universo é mais complexo do que se imagina e muito diferente daquilo que falamos a seu respeito, porque, como diria David Bohm, aquilo de que desejamos falar não são palavras. Essa convicção exige um permanente acordo democrático entre os diversos níveis de apreensão da realidade.

Em uma época científica mais ingênua, pensou-se que a subjetividade pertencia ao domínio da ilusão, que era preciso rejeitá-la, e que somente o saber objetivo era verdadeiro. Hoje se sabe bem que isso é falso. Essa subjetividade não é uma ilusão, é uma outra parte do real, não menos importante (ATLAN, 1993, p. 55).

Portanto, os sabores, os cheiros, as apreciações estéticas e os sentimentos humanos não podem ser reduzidos a uma qualificação de segunda categoria. Assombrado e encolhido diante de suas próprias conquistas, o homem moderno corre o risco de secundarizar a si mesmo e a vida do planeta. Contrário a esse projeto, o paradigma emergente caracteriza-se principalmente por uma nova postura diante dos saberes de senso comum. 
Enquanto a ciência moderna se constituiu a partir da ruptura epistemológica com o senso comum, a nova ciência deve orientar-se no sentido de uma segunda ruptura epistemológica que, conforme lembra Santos (2003), além de possibilitar o reencontro e a reabilitação dos saberes cotidianos, favorece a uma realimentação da própria ciência que, embora continue produzindo conhecimentos específicos e diferenciados, entende que esses conhecimentos devem ser popularizados e convertidos em senso comum, autoconhecimento e sabedoria de vida.

Nesse sentido, o paradigma científico emergente não pode ser apenas um novo modelo científico, mas, orientado pelo princípio da precaução, deve conduzir a um conhecimento prudente que, de acordo com Santos (2004a, 2004 b), assume como centralidade o projeto de uma vida decente.

Embora a ciência moderna tenha desenvolvido uma capacidade desmedida para a ação, não desenvolveu habilidade semelhante na previsão de consequências. Este desequilíbrio entre ação e consequência possibilitou a mitificação do progresso e a justificação do conhecimento pelo conhecimento, permitindo um profundo conhecimento funcional do mundo e alargando as perspectivas de sobrevivência da espécie humana. Ao mesmo tempo, elevou ao extremo os riscos de destruição completa do planeta. Este novo contexto de risco, nunca experimentado em períodos anteriores à ciência, exige mais que simples dados de sobrevivência. Não basta sobreviver, mas urge reaprender a viver, reconhecendo e eliminando os riscos de nossas intervenções no mundo. 
Com efeito, a ciência emergente sinaliza para uma outra modalidade de conhecimento mais compreensivo e íntimo que procura integrar o homem à realidade que estuda. Menos agressiva e mais compreensiva, afasta-se do conhecimento como pura expressão de poder, transgredindo os limites impostos pela racionalidade cognitivo-instrumental moderna, para recuperar aspectos fundamentais de uma racionalidade ética e estético-expressiva.

Em meio a essa confluência revolucionária, um traço marcante do paradigma nascente é o questionamento das antigas dicotomias sujeito/objeto; cultura/natureza; idealismo/materialismo; observador/observado que, por coerência deverá apontar para o fim da conhecida dualidade, ciências naturais/ciências sociais. Se a ciência moderna, dentro de um projeto cartesiano, desenvolveu-se considerando uma separação clara entre a res cogitans e a res extensa, ao avançar numa compreensão mais sutil da matéria estendida, confrontou-se com uma estrutura complexa, somente compreensível dentro de articulações matemáticas que, traduzidas em tecnologia, redefinem a matéria em um outro patamar. Portanto, a res extensa perde o seu caráter de substância independente e a cisão do mundo em processos objetivos de um lado e a mente na qual esses processos são refletidos, do outro, não é mais um ponto de vista apropriado ao paradigma científico emergente. Se a coisa em si realmente existisse, conforme pensou Heisenberg, seria uma estrutura matemática que, paradoxalmente ao que sugeriu Kant, dependeria indiretamente da experiência. Nesse caso, o esforço desenvolvido no sentido de estabelecer uma objetividade, a mais rígida possível, conduziu a uma crescente e estranha desmaterialização e subjetivação 
da natureza. Na física de partículas, por exemplo, a matéria é definida a partir de suas relações com as experiências humanas e pelas leis estabelecidas através da matemática, ou seja, como objeto intelectual e passível de manipulação. Considerados estes pressupostos, o paradigma emergente orienta a produção do conhecimento por caminhos que se afastam das antigas e conhecidas dualidades, que passam a ser encaradas de maneira não trivial e como relações complexas, estabelecendo fronteiras diferentes entre conhecimento científico-natural e conhecimento científico-social.

Conforme Maturana e Varella (2002), não há uma descontinuidade entre o social, o humano e suas raízes biológicas, ou seja, o fenômeno do conhecimento é um todo integrado e fundamentado da mesma forma em todos os seus âmbitos.

... estamos num mundo. No entanto, quando examinarmos mais como chegamos a conhecer esse mundo, descobriremos sempre que não podemos separar nossa história das ações - biológicas e sociais - a partir das quais ele aparece para nós (Idem, p.28).

De fato, os estudos em ciência, tecnologia e sociedade demonstram as ciências modernas como resultados emergentes de uma construção ${ }^{42}$ dinâmica que, no mínimo, envolve atores humanos, seres vivos, materiais diversos,

42 Por construção entende-se o processo através do qual elementos ou entidades heterogêneas (actores humanos, outros seres vivos, instrumentos, materiais, recursos institucionais, competências, tecnologias) são articuladas de modo a dar origem a algo que não existia antes, e que não se limita a uma simples soma dos elementos previamente existentes (NUNES, 2004). 
instrumentos, competências, apoio institucional e muito recurso financeiro (NUNES, 2004; LATOUR, 2000). Nesse caso, tanto o conhecimento natural como os objetos tecnológicos são construções humanas e a distinção simplista entre o real e o construído perde completamente o sentido. Todas as ciências são, portanto, humanas e sociais.

Este ponto de vista pode ser evidenciado através da emergência de novos campos de investigação que não se completam ou identificam apenas no contexto das ciências naturais ou no quadro das ciências sociais, mas que transcendem os antigos obstáculos entre as ciências, inaugurando importantes projetos interdisciplinares. Como exemplos de problemas atratores, podemos destacar: o aquecimento global e as mudanças climáticas, as ciências ambientais, os projetos ecológicos, os estudos da biodiversidade, as ciências cognitivas, além de muitos outros temas que, embora aparentemente dissociados, na verdade participam de uma realidade complexa e inerentemente implicada.

Uma outra característica fundamental do paradigma científico nascente e que está diretamente vinculada à anterior é a clara tendência para romper com a fragmentação disciplinar estabelecida ao longo do projeto de edificação da ciência moderna. Projeto que, em suas últimas consequências, aprofundou demasiadamente as especificidades não compartilhadas e conduziu ao isolamento e à esterilidade improdutiva de algumas disciplinas. Neste processo, que vai se tornando mais ou menos claro ao longo da década de noventa, o crescente número de novas especialidades, confinadas em estruturas departamentais acadêmicas, tornou-se insuficiente para dar resposta a uma realidade cada dia mais complexa. 
De acordo com Nunes (2004), a expansão da crise do paradigma científico hegemônico e os sinais de uma ciência emergente coincidem com uma série de transformações ocorridas na sociedade a partir da década de oitenta e que se desenvolve durante toda a década de 1990, até alcançar os dias de hoje. Com o fim da Guerra Fria, por exemplo, verifica-se uma forte retração dos recursos destinados a projetos relacionados às pesquisas direta ou indiretamente vinculadas à criação de novas tecnologias orientadas para a indústria da guerra. Neste processo, a física foi uma das ciências mais prejudicadas e a suspensão do gigantesco projeto para a construção de um superacelerador de partículas nos Estados Unidos, no início da década de noventa, confirma este fato.

Por outro lado, a ascensão das ciências da vida - com particular destaque para a Genética em sua conhecida e controvertida relação com o projeto de mapeamento do Genoma Humano - passou a ocupar lugar de destaque nos principais debates científicos da década de noventa, prosseguindo como discussão central até os dias atuais. Se, como já adiantamos aqui, o paradigma emergente envolve questões relacionadas ao fim das certezas, à irreversibilidade temporal, à auto-organização a partir do caos e outras características conflitantes com o modelo anterior, a ascensão das ciências ligadas à vida, colocará novas questões que, para além das especificidades disciplinares, exigirá o enfrentamento de problemas com implicações transversais às diferentes disciplinas.

É nesse contexto que nascem as novas experiências interdisciplinares e transdisciplinares em projetos que requerem o envolvimento da ciência com outras questões, 
mas, sobretudo, com as questões socioambientais. Os estudos em ciência e meio ambiente e de ciências, tecnologia e sociedade são exemplos importantes desses novos espaços alargadores dos horizontes disciplinares e que reúnem cientistas de várias áreas diferentes, num esforço conjunto por compreender a realidade em uma totalidade maior, levando em consideração diversos aspectos, certamente negligenciados em uma visão disciplinar mais estreita. Talvez o ensino de ciências revele com alguma vantagem esse processo de transformação que estamos reconhecendo como o prenúncio de um novo paradigma científico. Em suas Orientações Educacionais Complementares, os Parâmetros Curriculares Nacionais (2002) sugerem uma nova contextualização sociocultural para o ensino das ciências, de modo que, o conhecimento científico e tecnológico seja compreendido como resultado de uma construção humana, inserida em um processo histórico e social mais amplo, que o revele como integrante da cultura geral. Alguns estudos e artigos recentes revelam, de maneira clara, os sinais dessa nova tendência. "Salvador Dali e a mecânica quântica", Costa (2007); "Ciência e Arte: Vermeer, Huygens e Leeuwenhoek” , Barbosa-Lima (2007); "Teatro e Educação Ambiental: uma experiência no ensino fundamental" Silveira (2007); "Física e Cultura" Zanetic ( 2005); "Quando o Sujeito se Torna Pessoa: uma articulação possível entre Poesia e Ensino de Física" Barbosa-Lima (2004); "Física e Arte: uma ponte entre as duas culturas" Zanetic (2006). É claro que esta é uma amostra muito pequena dentro do universo de publicações dessa natureza, mas serve para ilustrar o argumento que estamos defendendo aqui. 
Por outro lado, a nova maneira de ensinar ciências será fundamental para a formação de cientistas comprometidos com o modelo nascente que, não custa repetir, entre outras características, deve orientar-se pela precaução de um conhecimento prudente, democrático e comunicativo.

No contexto do paradigma emergente, as novas tecnologias devem considerar os impactos provocados nos ecossistemas; a medicina deverá reencontrar o doente e não as doenças isoladas; os remédios e as novas fórmulas químicas reorientam-se pelos riscos dos efeitos colaterais, as indústrias de biotecnologia são questionadas a levar em consideração os impactos ambientais, as investigações genéticas são avaliadas e pressionadas a considerar os apelos sociais, enfim, todas as ciências voltarão o "olhar" para uma totalidade mais ampla e que transcenda os necessários, mas reconhecidamente limitados, pontos de vista específicos.

Na medicina e na produção de alimentos, por exemplo, já se verifica uma via de mão dupla que ultrapassa o monopólio, a credibilidade e a eficácia do discurso científico veiculado através da alopatia e da farmacologia tradicional, contrapondo-lhe o contraefeito produzido por movimentos sociais alternativos em favor de novas formas de tratamento e novos medicamentos homeopáticos. Como consequência, os órgãos especializados absorvem parte dessa crítica e incorporam algumas das reivindicações mais amplas da sociedade (FLORIANI, 2000).

Nesse sentido, o novo espaço que nasce com o paradigma científico emergente é um espaço que, além de físicos, químicos, matemáticos, engenheiros e biólogos, abrigará também, sociólogos, historiadores, antropólogos, 
filósofos, cientistas políticos, psicólogos, ambientalistas, movimentos sociais, organizações não-governamentais, órgãos de defesa dos direitos humanos e muitas outras formas de saberes negligenciados pela academia moderna.

Por outro lado, conforme já adiantamos no capítulo anterior, o paradigma científico emergente orienta-se a partir de uma nova racionalidade que, embora não despreze, transcende o modelo de racionalidade cognitivo e instrumental moderno e avança para um modelo mais abrangente. É em Santos (2004b) que vamos encontrar uma caracterização deste modelo hegemônico de racionalidade, como também a formulação de uma crítica consistente e orientada pelo anúncio de possibilidades utópicas de um novo tipo de racionalidade.

De certa forma, no capítulo anterior, já adiantamos os fundamentos principais do pensamento de Santos em sua consistente crítica a certo tipo de racionalidade que ele definiu como razão indolente, isto é, uma razão preguiçosa que não se esforça no pensamento, acomodando-se na superfície das questões e ao abrigo do modelo de racionalidade herdeiro da ciência moderna. Em seus quatro formatos mais visíveis (metonímia, proléptica, impotente e arrogante), a razão indolente tem conseguido presidir os principais debates de nosso tempo, funcionando como uma barreira de contenção que obstaculiza o desenvolvimento de uma nova crítica mais consistente e genuína. Por conseguinte, para que haja uma mudança considerável na estruturação do conhecimento, é necessário construir um outro modelo de racionalidade que enfrente, de maneira contundente e criativa, as armadilhas e obstáculos postos pela razão indolente. 
Contra o domínio da razão indolente, Santos (2004b) propõe uma racionalidade cosmopolita cujas características principais, na fase de transição, em que nos encontramos são: a expansão do presente e a contração do futuro. Se o modelo hegemônico de racionalidade estabeleceu como princípios a contração do presente e a dilatação do futuro, na contramão desse projeto, Santos sugere a construção de duas novas sociologias: para a expansão do presente, uma sociologia das ausências e para a contração do futuro, uma sociologia das emergências.

Sem dúvida, encontramo-nos diante de uma tese inovadora, fecunda e muito importante para os objetivos de nossa argumentação em defesa de uma ciência emergente que se pretende comunicativa e popular. Nesse sentido, o fato de estarmos confinados a um modelo de racionalidade que credita à ciência moderna o privilégio de único pensamento rigorosamente racional e desacredita de todas as outras formas e expressões de saberes, constitui um sério obstáculo no caminho de um diálogo horizontal entre saberes. É com base nesse princípio autoritário de razão única que são produzidas e reproduzidas as exclusões e ausências para as quais Santos chama a nossa atenção.

A princípio, temos que identificar as ausências, reconhecendo no não existente um não existente produzido ativamente como uma alternativa inviável ao que já existe, ou seja, como afirmação de uma realidade intransponível que anula o princípio de possibilidade. As exclusões e ausências não são contingenciais, pelo contrário, são produzidas ativamente com base no princípio de regulação que acabou por dominar pensamento da modernidade. Nesse contexto, o objetivo da sociologia das ausências é resgatar 
o poder emancipatório do princípio de possibilidade, transformando objetos e objetivos impossíveis em possíveis e as ausências em emergências (SANTOS, 2004b).

Um exemplo que ilustra muito bem este fato são os estudos e pesquisas da biodiversidade que, sem o imprescindível auxílio e orientação dos saberes indígenas, dos guias e mateiros e das comunidades ribeirinhas, seria completamente impossível. No entanto, a visão indolente da ciência, como única fonte de saber, continua produzindo a ausência destes, como de muitos outros saberes que, uma vez sistematizados e apropriados pela ciência, são desqualificados e esquecidos.

Este modelo de racionalidade única tem produzido um enorme desperdício de experiências que, ao serem desconsideradas, passam a assumir o caráter de não existentes. A recusa em observar e considerar a riqueza que se passa no presente defronta-nos com outra característica da modernidade: uma estranha e crescente contração do tempo presente, fenômeno que se tornou possível a partir de uma concepção particular de totalidade que passou a definir o presente como um instante limite ${ }^{43}$ entre o passado e o futuro.

A partir de uma visão linear do tempo, do mito do progresso e da planificação e presentificação do futuro, constrói-se uma estranha contração do presente e, de outro lado, a visão de um futuro que se projeta ao infinito. As ideias de progresso, crescimento e futuro infinitos têm esmagado e subsumido toda a riqueza e novidade das experiências presentes. E, só através de uma dilatação do presente, associada a uma contração do futuro, "será

43 Estamos utilizando uma aproximação do conceito de limite matemático. 
possível criar o espaço-tempo necessário para conhecer e valorizar a inesgotável experiência social que está em curso no mundo de hoje" (SANTOS 2004b, p.779).

Enquanto a sociologia das ausências identifica e denuncia as ausências produzidas pela razão indolente, a sociologia das emergências procura resgatar e incorporar saberes e experiências humanas que, de acordo com Santos (2000), mesmo pequeninas, funcionam como embriões de alternativas, a exemplo da economia solidária, das cooperativas, dos micro-créditos e inúmeros outros projetos contrapostos ao modelo hegemônico do capitalismo global.

Contra a lógica do rigor e da monocultura do saber que estabeleceram a ciência moderna e a alta cultura humanista como critérios únicos de verdade e qualidade estética, convertendo-as no mais poderoso veículo de exclusão e produção de ausências, é necessário contrapor o que ele denomina de ecologia de saberes, isto é, a identificação e resgate de outros saberes e outros critérios de rigor cuja credibilidade e sentido são encontrados em outros contextos e práticas sociais, desconsiderados pela razão indolente.

Essa credibilidade contextual deve ser considerada suficiente para que o saber em causa tenha legitimidade para participar de debates epistemológicos com outros saberes, nomeadamente, com o saber científico. A ideia central da sociologia das ausências neste domínio é que não há ignorância em geral nem saber em geral. [...] Deste princípio de incompletude de todos os saberes decorre a possibilidade de diálogo e disputa epistemológica entre os diferentes saberes (SANTOS, 2004b, p. 790). 
Por outro lado, considerando que as inúmeras experiências sociais emergentes não podem ser reunidas em uma teoria geral e universal, será necessário um esforço permanente de tradução no sentido de tornar possível a comunicação entre as várias experiências, sem, contudo, prejudicar suas identidades particulares. Eis o desafio a que se expõem aqueles que pretendem atuar no universo a que estamos denominando de popularização da ciência $e$ tecnologia. Como manter viva a relação com a cultura científica a qual pertencemos e, ao mesmo tempo, reconhecer os valores de outras práticas e saberes que a nossa cultura, de maneira autoritária, classificou como: inferior, superficial e ignorante?

Só apoiados em um outro referencial de ciência e em uma nova e diferente concepção de racionalidade, podemos enfrentar o desafio de uma comunicação transitiva e de um diálogo horizontal envolvendo os conhecimentos sistematizados da ciência e os saberes de senso comum.

Todo o nosso esforço concentra-se em demonstrar que não é qualquer visão de ciência que pode pretender-se popular. Esta adjetivação exige toda uma reformulação de pensamentos e atitudes que, naturalmente, são incompatíveis com alguns dos principais fundamentos da ciência moderna, sobretudo no que se refere a sua postura diante do senso comum. 


\section{Entre rupturas e continuidades: reencontrando o senso comum}

Uma das primeiras questões que obstaculiza a busca de fundamentos teóricos para as práticas em popularização da ciência e tecnologia refere-se à problemática relação entre conhecimento científico e saberes de senso comum. Essas duas formas de conhecer parece excluírem-se em seus critérios de explicação da realidade. Desse modo, se a ciência desenvolve-se em clara negação aos saberes de senso comum, como afirmar a possibilidade de sua popularização? Como refazer um caminho inverso de reaproximação e diálogo entre estes dois discursos que pretendem explicar uma mesma realidade por caminhos tão flagrantemente diferentes?

Não é simples estabelecer com precisão o momento em que aparece um recorte entre conhecimentos de senso comum e conhecimentos de bases filosóficas e científicas. Além de questões relativas à divisão do trabalho e aos conflitos e desigualdades sociais, muitos outros fatores parecem intervir em fenômenos dessa natureza, revelando a complexidade de um processo que acompanha o homem desde a gênese de sua cultura.

Já nos poemas de Homero e Hesíodo, encontramos alguns traços dessa qualificação. Conforme escreve Melo Neto (2004), a poesia de Homero é mais voltada ao mundo e à cultura dos nobres, dando maior ênfase a uma educação aristocrática para a qualidade tanto dos nobres como dos heróis. No caso de Hesíodo, há uma poesia arraigada à terra e à representação da vida campestre, mais rústica, mais simples e mais próxima do trabalho. Portanto, mais próxima de um conhecimento de senso comum. 
$\mathrm{Na}$ escola pitagórica, verifica-se mais acentuadamente a elaboração de explicações matemáticas de natureza mais abstrata e que escapam ao entendimento daquele conhecimento que estamos classificando de conhecimento do senso comum. Também em Platão, o estabelecimento da conhecida dualidade entre o mundo das ideias e o mundo dos sentidos, com o reconhecimento da superioridade do primeiro sobre a precariedade do segundo, revela uma cisão hierárquica entre as duas formas de conhecimento. Para Trindade (2001), no mito da caverna esta desqualificação do senso comum é mais explícita, sobretudo, quando Platão distingue os homens e a qualidade de seus conhecimentos. Os da caverna, representando o homem comum e seu "conhecimento" equivocado e baseado em falsas imagens reveladas pelos sentidos (senso comum), e o filósofo, representando uma espécie de "cientista" que conseguiu alcançar o conhecimento verdadeiro. Portanto, se o conhecimento filosófico é superior a outras formas de "conhecimento", caberá aos "filósofos" o papel de difundir esta verdade.

Até mesmo em Aristóteles, considerado por seus adversários renascentistas como o filósofo do senso comum e protagonista de uma filosofia natural apoiada em observações de qualidade secundária, reconhecemos uma clara separação entre o conhecimento próprio das reflexões filosóficas e os conhecimentos ligados às técnicas e atividades práticas reservadas às mulheres e aos escravos.

$\mathrm{Na}$ época medieval, não vai ser diferente. Fortemente marcada pela influência da Igreja Católica Romana, o medievo estabelece uma hierarquia no caminho de acesso ao conhecimento, transformando o cristianismo, religião de origem popular e ligada ao apelo comum dos oprimidos, 
em um credo dogmático e corrompido que negará o acesso direto ao sagrado e condicionará a fé e a salvação dos homens à necessária mediação dos líderes da Igreja, estabelecendo uma cisão entre o sagrado (onde reside o conhecimento verdadeiro) e o profano (onde se coloca o conhecimento de senso comum) e proibindo, entre outras coisas, o acesso à Bíblia Sagrada.

É contra essa época que se insurge o Renascimento, trazendo consigo um novo interesse pelos clássicos gregos e estabelecendo os fundamentos de uma nova ciência, uma "nova religião" e uma nova sociedade: a sociedade burguesa.

A Reforma Protestante, aliada ao nascimento da imprensa, permitirá um acesso direto aos textos sagrados e impulsionará o movimento pela alfabetização popular, possibilitando uma melhor qualificação do senso comum. Paradoxalmente, a revolução copernicana inaugura um processo contrário em que o conhecimento científico deveria superar os obstáculos dessa forma de saber que, apoiada no falso testemunho dos sentidos, conduziria a um tipo de conhecimento classificado por Kepler e Galileu como sendo de "qualidade secundária" e inferior, devendo, pois, ser submetido a um outro, de "qualidade primária" e próprio das matemáticas.

Assim como o olho foi feito para ver as cores e o ouvido para ouvir os sons, assim também a mente humana foi feita para compreender não o que quer que queira, mas sim quantidades (...) (Kepler apud Burtt, 1991, p.52). 
A ciência moderna nasce declarando guerra ao senso comum e estabelecendo como princípio uma hierarquia na qualidade do conhecimento: enquanto aqueles adquiridos através dos sentidos possuíam qualidade inferior e secundária, os alcançados através da razão dispunham de um status superior e de qualidade primária. Todo o progresso da ciência, determinista e fragmentária, foi construído sob essas bases, que não deixaram de ser importantes para certo tipo de compreensão da realidade.

Decerto que o conceito negativo de senso comum não partiu do próprio senso comum, mas, como afirma Alves (1985), é uma distinção oriunda da ciência, isto é, de um conhecimento que se especializa e se afasta passando a julgar e condenar o outro.

Enquanto conceito filosófico, a ideia de senso comum surgiu no século XVIII, representando o combate ideológico da burguesia contra o velho regime e, como escreve Santos (2003, p. 36), trata-se "de um senso que se pretende natural, razoável, prudente, um senso que é burguês e que, por uma dupla implicação, se converte em senso universal". Porém, com a vitória do projeto burguês, era natural que caísse em desvalorização e descrédito sendo reduzido a um conhecimento ilusório e de segunda categoria. É, portanto, nesse contexto de crítica à sociedade burguesa do século XIX que se erguem as ciências sociais em seu conhecido combate aos saberes de senso comum.

Se do ponto de vista das ciências naturais, o testemunho dos sentidos é insuficiente e na maioria dos casos, só induz ao erro, do ponto de vista das ciências sociais, as ideias forjadas a partir de opiniões cotidianas só refletem 
a ideologia das classes dominantes. É neste contexto que cumpre perguntar: para que serve mesmo o senso comum?

Pensamos que a partir da resposta para essa questão se estabelecerão as diretrizes e linhas de atuação no universo do que estamos chamando de PopCETT. Como já afirmamos em capítulos anteriores, as opiniões e intervenções neste universo não são uniformes e nem consensuais.

\section{As rupturas epistemológicas de Bachelard}

O encontro de Bachelard com o problema do senso comum dar-se-á através de sua indagação a respeito de como pode haver avanço no conhecimento científico. No clássico, "A Formação do Espírito Científico. Contribuição para uma Psicanálise do Conhecimento", o filósofo francês responde a essa questão introduzindo o conceito de "obstáculos epistemológicos". Para o autor, é em termos de obstáculos que a questão do desenvolvimento científico deve ser colocada, não em termos de obstáculos externos como a complexidade ou fugacidade dos fenômenos, e nem como a admitida culpa atribuída à fragilidade dos sentidos, mas

...é no âmago do próprio ato de conhecer que aparecem, por uma espécie de imperativo funcional, lentidões e conflitos. É aí que mostraremos causas de estagnação e até de regressão, detectaremos causas de inércia às quais daremos o nome de obstáculos epistemológicos (BACHELARD, 1996, p.17). 
Embora não coloque a culpa diretamente nos sentidos e nem na fragilidade do espírito humano, o termo cunhado por Bachelard aponta uma série de atitudes e valores que de alguma forma obstaculizam o desenvolvimento do conhecimento científico e da própria ciência. Curiosamente, o senso comum aparece como um dos principais exemplos dessas atitudes. Juntamente com o preconceito, a ideologia, a idolatria e a opinião, o senso comum figura, numa concepção bachelardiana, como um dos primeiros e mais importante, obstáculos epistemológicos ao desenvolvimento do conhecimento científico. "Na formação do espírito científico, o primeiro obstáculo é a experiência primeira, a experiência colocada antes e acima da crítica - crítica esta que é, necessariamente, elemento integrante do espírito científico" (BACHELARD, 1996, p.29). Para o autor, o espírito científico deve formar-se contra a natureza, contra o que em nós e fora de nós aparece como impulso e informação da natureza, contra o arrebatamento natural e os fatos coloridos e corriqueiros.

Nesse caso, conforme o pensamento bachelardiano, uma satisfação apressada à curiosidade ao invés de benefício pode tornar-se um novo obstáculo epistemológico, substituindo o conhecimento pela simples admiração e as ideias pelas imagens.

Conforme Bachelard (1996), diante do fascínio da realidade, a alma corre o risco de tornar-se ingênua e não superar os conhecimentos habituais. Diante do real, aquilo que, em princípio, acreditamos saber com clareza, ofusca o que, de fato, deveríamos saber. 
Outro importante obstáculo apontado na construção bachelardiana é a opinião. Para o autor, a opinião pensa mal ou não pensa e ao traduzir necessidades em conhecimentos e designar os objetos pela utilidade, interdita o conhecimento. Nesse caso, cumpre, antes de tudo, destruí-la (Idem). Além destes, a generalidade ou o conhecimento generalista também figura na filosofia de Bachelard como um forte obstáculo epistemológico. Para ele, " Nada prejudicou tanto o progresso do espírito científico quanto a falsa doutrina do geral, que dominou de Aristóteles a Bacon, inclusive, e que continua sendo, para muitos, uma doutrina fundamental do saber" (BACHELARD, 1996, p.69). De fato, prossegue, "há um perigoso prazer intelectual na generalização apressada e fácil ...”, o que imobiliza o pensamento e ofusca a verdade (Idem, p.72). Portanto, no contexto das ideias bachelardianas, tanto a generalização como o conhecimento unitário e pragmático são classificados como importantes e difíceis obstáculos epistemológicos.

Conforme o pensamendo de Bachelard (1996, p.11), a formação do espírito científico desenvolve-se através de três estados: o estado concreto, o estado concreto-abstrato e o estado abstrato. No primeiro estado, o espírito ainda se entrete com as primeiras imagens do fenômeno, apoiando-se na filosofia, exaltando a natureza e louvando curiosamente a unidade e a diversidade do mundo. No estado concreto-abstrato, embora inseguro de sua abstração, acrescenta esquemas geométricos às experiências físicas, apoiando-se em uma filosofia da simplicidade em que as abstrações ainda são representadas por uma espécie de intuição sensível. Por fim, no estado abstrato, o espírito 
adota informações voluntariamente subtraídas à intuição do espaço real, voluntariamente desligadas da experiência imediata e até em polêmica com a realidade primeira, sempre impura e informe. É no percurso desses estados que se encontram os obstáculos epistemólógicos, prejudicando o desenvolvimento científico e construindo uma ciência precária e sustentada nas inconsequências do senso comum.

\section{Senso comum e ideologia: uma resposta gramsciana}

É no contexto de recuperação de um significado orgânico das ideologias que se encontra a resposta de Gramsci para o lugar do senso comum dentro da estrutura ideológica. Conforme o marxista italiano, a afirmação e difusão da ideologia é um processo pensado e guiado hegemonicamente, isto é, os grupos sociais, econômica e politicamente dominantes, difundem, através de uma estrutura ideológica organizada, a sua visão de mundo que passa a ser absorvida pela maioria da sociedade. Num estado mais elevado, esta concepção de mundo é incorporada como filosofia, num estado inferior, como folclore e num estado intermediário, como religião e senso comum. Portanto:

A filosofia do senso comum é a filosofia dos não filósofos, isto é, a concepção do mundo absorvida acriticamente pelos vários ambientes sociais e culturais nos quais se desenvolve a individualidade moral do homem médio (GRAMSCI, 1981, p. 143). 
Nesse caso, distante de uma concepção original e coerente própria das classes populares, o senso comum caracteriza-se como uma visão distorcida, desagregada e incoerente do mundo; uma compreensão difusa de uma realidade marcada pela presença da ideologia dos grupos dominantes. Por conseguinte, avançar do senso comum para a consciência filosófica "significa passar de uma concepção fragmentária, incoerente, desarticulada, implícita, desagregada, mecânica, passiva e simplista a uma concepção unitária, coerente, articulada, explícita, original, intencional ativa e cultivada" (SAVIANI, 1980, p.10). Essa passagem exigirá uma educação comprometida com a construção de uma nova hegemonia, além de uma nova categoria de intelectuais engajados com a formação e os interesses das classes populares. Nesse processo, Gramsci reconhece que, não existindo nenhuma atividade humana na qual se possa excluir toda intervenção intelectual, todos os homens são intelectuais.

No seu trabalho, que nunca pode ser reduzido só à capacidade técnica-manual (enquanto trabalho humano), mas também, fora do seu trabalho cada homem é um intelectual, um filósofo, enquanto participa de uma determinada concepção do mundo, tem gostos artísticos e se comporta de acordo com uma linha de conduta moral... (GRAMSCI, 1979, p. 8).

Com efeito, mantendo-se coerente com a ideia de que todo homem é filósofo, o autor reconhece a presença de um núcleo positivo no senso comum o qual denomina de 
"bom senso". Apesar de envolto na contradição entre suas próprias falas e crenças e as tradições herdadas e veiculadas pelos grupos dominantes, é possível resgatar do senso comum o seu núcleo positivo de bom senso, tarefa que caberá aos intelectuais organicamente ligados aos interesses populares. Portanto, numa visão gramsciana:

A filosofia da práxis não busca manter os "simplórios" na sua filosofia primitiva do senso comum, mas busca, ao contrário, conduzi-los a uma concepção de vida superior. Se ela afirma a exigência do contato entre os intelectuais e os simplórios não é para limitar a atividade científica e para manter uma unidade ao nível inferior das massas, mas justamente para forjar um bloco intelectual-moral, que torne politicamente possível um progresso intelectual de massa ... (apud SAVIANI, 1980, p.14).

Como fica evidente, Gramsci não entende o senso comum como algo estático e acabado, mas como um processo no qual, em contato com os intelectuais, pode ser enriquecido com noções científicas e filosóficas que gradativamente penetram nos costumes. O senso comum é considerado o folclore da filosofia e, numa visão gramsciana, ocupa sempre um lugar intermediário entre o folclore propriamente dito e a filosofia (GRAMSCI, 1979). De qualquer forma, é tarefa da filosofia da práxis superar a ideia equivocada de que o senso comum é uma filosofia original e autônoma dos grupos populares, desmascarando a sua realidade contraditória e alienada. 


\section{Das rupturas a superação: a resposta de Paulo Freire}

Paulo Freire, em sua prática inicialmente vinculada ao problema da alfabetização de adultos, também vai deparar-se com a problemática relação entre o conhecimento sistematizado e os saberes cotidianos e de senso comum. Se, conforme o autor, a leitura do mundo precede à leitura da palavra, esta deveria ser desenvolvida dentro de um processo de conscientização ${ }^{44}$, numa intervenção que conduzisse a uma superação da consciência ingênua em favor de uma consciência crítica. De acordo com Freire (1980, p. 26), "na aproximação espontânea que o homem faz do mundo, a posição normal fundamental não é uma posição crítica, mas uma posição ingênua". A conscientização implica um afastamento da apreensão espontânea da realidade e uma postura crítica em que o homem assume uma atitude epistemológica. Contudo, diferente da concepção bachelardiana, defende a ideia de que entre a ingenuidade e a criticidade, entre os saberes de experiência e os que resultam de procedimentos metodologicamente rigorosos não há uma ruptura, mas uma superação. É na obra, "Pedagogia da Autonomia: saberes necessários à prática educativa" que expressa muito claramente sua opinião a respeito desta questão.

$\mathrm{Na}$ verdade, a curiosidade ingênua que, "desarmada", está associada ao saber de senso comum, é a mesma curiosidade que, criticizando-se, aproximando-se de forma cada vez mais metodologicamente rigorosa

44 De acordo com Paulo Freire, o termo conscientização foi criado por uma equipe de professores do Instituto Superior de Estudos Brasileiros por volta de 1964. Entre os professores, figuravam os nomes de Vieira Pinto e Guerreiro (FREIRE, 1980, p.25) 
do objeto cognoscível, se torna curiosidade epistemológica. Muda de qualidade, mas não muda de essência (FREIRE, 1996, p.31).

Nesse sentido, ele discorda da ideia de ruptura epistemológica cunhada por Bachelard e substitui o termo pela palavra superação. De modo que, no processo em que a curiosidade ingênua, sem deixar de ser curiosidade e, pelo contrário, continuando a sê-lo, criticiza-se, não há uma ruptura, mas uma superação.

No entanto, a superação de uma visão ingênua da realidade não se dará através dos comunicados e imposições das lideranças revolucionárias. É no diálogo que o autor deposita todas as suas esperanças. É necessário acreditar nos homens oprimidos, na sua capacidade de pensar certo também. "Se esta crença nos falha, abandonamos a ideia ou não a temos, do diálogo, da reflexão, da comunicação e caímos nos slogans, nos comunicados, nos depósitos, no dirigismo" (FREIRE, 1981, p.57). Nesse sentido, o autor reafirma em sua "Pedagogia da Esperança": "O que não é possível - repito-me agora - é o desrespeito ao saber de senso comum; o que não é possível é tentar superá-lo sem, partindo dele, passar por ele" (FREIRE 1999, p.84).

Por outro lado, embora tenha afirmado que "ninguém educa ninguém", Paulo Freire reafirma a necessária presença dos educadores populares junto ao povo oprimido quando lembra que é necessário desafiar os educandos em relação ao que pensam ser o seu acerto.

Que educador seria eu se não me sentisse movido por forte impulso que me faz buscar, sem mentir, argumentos convincentes na 
defesa dos sonhos por que luto? Na defesa da razão de ser da esperança com que atuo como educador (Freire, 1999, p.84).

Não podemos, acuados pelo medo de uma suposta invasão cultural, negar que as classes populares possam seguir, para além de suas crenças e "saberes de experiência feitos" do senso comum, até um conhecimento mais metódico, rigoroso e sistemático como é o caso do conhecimento científico.

Para o autor, desvelar a razão de ser das coisas e ter delas uma visão mais profunda e cabal, não pode ser privilégio das elites. No entanto, se os grupos populares desconhecem, de forma crítica, como a nova sociedade tecnológica funciona, certamente devido às condições precárias em que foram sendo proibidos de ser e de saber, a saída não pode se dar através da propaganda ideológica e de uma divulgação massiva de conhecimentos científicos. Mas, encontra-se no diálogo e no intransigente respeito ao conhecimento de "experiência feito".

Possivelmente foi a convivência sempre respeitosa que tive com o "senso comum", desde os idos de minha experiência no Nordeste brasileiro, a que se junta a certeza que em mim nunca fraquejou de que sua superação passa por ele, que me fez jamais desdenhá-lo ou simplesmente minimizá-lo (Freire, 1999, p.58).

Portanto, a leitura do mundo não pode ser a nossa leitura imposta às classes populares de maneira vertical e 
messiânica. Não podemos crer, como sugere Erica Marcuse, que somos parte de um grupo especial da sociedade, possuidores de uma consciência crítica "dada", entendendo-nos como pessoas já libertadas ou inalcançáveis pela dominação e cuja tarefa é ensinar e libertar os outros (apud FREIRE, 1999).

Por outro lado, é importante repetir, não se trata também de silenciar diante do conhecimento do senso comum. A posição dialética e democrática, acrescenta Freire (1999), exige uma clara e explícita intervenção do intelectual como condição indispensável à sua tarefa, sobretudo, no que se refere a uma necessária e imperiosa familiaridade com o universo popular onde pretende atuar.

É neste sentido que volto a insistir na necessidade imperiosa que tem o educador ou a educadora progressista de se familiarizar com a sintaxe, com a semântica dos grupos populares, de entender como fazem eles sua leitura do mundo, de perceber suas "manhas" indispensáveis à cultura de resistência que se vai constituindo e sem a qual não podem defender-se da violência a que estão submetidos. Entender o sentido de suas festas no corpo da cultura de resistência, sentir sua religiosidade de forma respeitosa, numa perspectiva dialética e não apenas como se fosse expressão pura de sua alienação. Respeitá-la como direito seu, não importa que pessoalmente a recuse de modo geral, ou que não aceite a forma como é ela experimentada pelo grupo popular (FREIRE, 1999, p.107). 
Portanto, o diálogo, mesmo quando construído a partir de horizontes culturais diferentes, pode, a partir do reconhecimento e respeito do universo vocabular do outro, produzir uma situação emancipadora para ambos. Por isso mesmo, continua Freire (1999), não nivela, não reduz um ao outro, nem é tática manhosa, que se usa para envolver o outro. Implica, ao contrário, um respeito fundamental dos sujeitos nele envolvidos, que o autoritarismo não permite que se constitua.

\section{O senso comum na psicologia social: a visão de Moscovici}

No caso de Serge Moscovici ${ }^{45}$, a conhecida "Teoria das Representações Sociais" por ele incorporada ao universo da psicologia social, teria sido construída em função da resposta a uma convicção de que o lugar do senso comum estava mal resolvido, tanto no território das ciências naturais como nos limites das ciências sociais. Conforme o autor romeno, o senso comum não poderia continuar sendo tratado como algo irracional e incoerente, mas, pelo contrário, deveria ser encarado como um importante terceiro fator entre o conhecimento científico e a ideologia.

Preocupado com a questão do impacto causado pela ciência na cultura das massas, Moscovici discorda da posição marxista em relação ao caráter e ao lugar do senso comum. Para ele, "Os marxistas - ou mais precisamente

45 Serge Moscovici, nascido na Romênia, dirigiu estudos na École des Hautes Ëtudes em Sciences Sociales, Paris. Também lecionou por muitos anos na New School for Social Research, Nova Iorque. Entre suas obras principais destacam-se: La psychanalyse: Son image et son public (1961); Social Influence and Social Change (1976); The Invention of Society (1989), (MOSCOVICI, 2003). 
Lênin!- desconfiavam do conhecimento espontâneo e do pensamento das massas" (MOSCOVICI, 2003, p. 309). Tal convicção teria sustentado a ideia de que os conhecimentos de senso comum deveriam ser purificados de suas irracionalidades ideológicas, religiosas e populares, devendo ser substituído por uma concepção científica do ser humano, da história e da natureza, visão que estaria vinculada à concepção marxista e materialista da história. Em certo sentido, prossegue Moscovici (Idem p. 310), o objetivo era transformar todos os seres humanos em quase cientistas, fazendo-os pensar de uma maneira racional e objetiva. Por outro lado, e, paradoxalmente, considerava-se a comunicação, popularização ou, em uma terminologia francesa, a vulgarização da ciência uma espécie de caricatura que desvirtuava o conhecimento científico em sua versão original. Nesse particular, havia uma convergência entre marxistas e não marxistas, isto é, para ambas as correntes, o conhecimento de senso comum era contaminado, deficiente e errado. Opondo-se a esta corrente de pensamento, Moscovici tenta reabilitar o conhecimento comum, próprio das experiências diárias, linguagens e práticas cotidianas, ao mesmo tempo em que reage contra a ideia de que o povo é incapaz de pensar racionalmente e apenas os intelectuais são portadores de tal privilégio. Para o autor,

pessoas e grupos, longe de serem receptores passivos, pensam por si mesmos, produzem e comunicam incessantemente suas próprias e específicas representações e soluções às questões que eles mesmos colocam ... Os acontecimentos as ciências e as ideologias apenas lhes fornecem o "alimento para o pensamento” (MOSCOVICI, 2003, p.45). 
Portanto, o pensamento de senso comum é considerado razoável, sensível e racional e deve ser entendido como aquele terceiro fator que liga os indivíduos à sua cultura, à sua linguagem e ao seu mundo familiar. Assim como o mito para a antropologia, os sonhos para a psicanálise e o mercado para economia, o senso comum é, para Moscovici, a matéria prima da psicologia social. Aos seminários ministrados por Alexandre Koyré ${ }^{46}$, o autor atribui o despertar dos primeiros argumentos de como o senso comum pode ser coerente em sua própria lógica, diferente da lógica da ciência. A física aristotélica é um exemplo. Embora construída a partir de observações cotidianas, fundamentadas em qualidades sensoriais (qualidades secundárias) e em explicações teleológicas de causas finais, não podemos considerá-la ilógica e absurda como se pensava antes de Koyré.

O senso comum tem suas próprias características e, ao contrário do pensamento científico que, de maneira ideal, pode ser compreendido independentemente do conteúdo e através de formalizações lógico-matemáticas, o pensamento comum, não pode ser dividido em dois; o conteúdo infecta o raciocínio, tornando-o plausível e, sem isso, a forma torna-se incompreensível e sem sentido. É na infância que, muito cedo, a marca do senso comum é adquirida, justamente através da comunicação oral. Não é curioso que, mesmo

46 Nascido na Rússia, em Tarangog, em 1892, Alexandre Koyré seguiu entre 1908 e 1911 os cursos de Husseri e Hilbert, em Gottingen, vivendo depois em Paris, onde acompanhou os cursos de Bérgson e Brunschwig. Começou por elaborar uma tese sobre Jacob Bohme e publicar vários estudos filosóficos (sobre St. Anselmo, Spinoza), dedicando-se seguidamente a história da ciência, área onde produziu várias obras fundamentais: Etudes galiléenns(1939), From the closed World to the infinite Universe (1957), La révolution astronomique(1961) e Etudes newtoniennes (1964) (KOYRÉ, 1992). 
sem nenhum estudo, as pessoas aprendam a falar com perfeição a sua língua materna? Com efeito, o conhecimento de senso comum não deve ser considerado distorcido e errado como muitas vezes se supôs. Na realidade, ele se adequa perfeitamente aos propósitos e necessidades cotidianas "e chegou mesmo a encantar e tornar a vida digna de ser vivida durante muitos séculos" (MOSCOVICI, 2003, p.336).

Por outro lado, embora admitindo certa cautela, sugere a hipótese da polifasia cognitiva. Assim como a linguagem é polissêmica, o conhecimento é polifásico e as pessoas usam diferentes modos de pensamento e diferentes representações, dependendo do grupo específico ao qual pertençam e ao contexto em que estão no momento. Nesse caso, nem cientistas nem filósofos estão imunes aos mesmos vícios imputados ao senso comum. Não existem pessoas monofásicas e imbuídas de uma única e privilegiada maneira de pensar.

Muitos cientistas possuem um credo religioso, outros são racistas, alguns consultam os astros e em algumas situações fazem uso de explicações em bases aristotélicas. Se essas diferentes e até mesmo conflitantes formas de pensamento não coexistissem em suas mentes, elas não seriam mentes humanas. Do mesmo modo, não há razão para crer que apenas uma forma única e pura de pensamento (a científica) irá prevalecer no futuro. (Idem, p.328).

Ao contrário do que se esperava, longe de tornarem-se antídotos contra as representações sociais e ideologias, as ciências, na realidade, dão origem a novas representações. De fato, conforme Moscovici (Idem, p.60), a multiplicação de teorias, informações e acontecimentos exigem que novos mundos sejam reproduzidos a um nível mais imediato e acessível. 
Se antes a ciência baseada no senso comum o tornava menos comum, agora o senso comum é a ciência tornada comum. Nesse caso, o senso comum estaria em contínua criação e recriação em nossas sociedades, sobretudo onde o conhecimento científico e tecnológico está sendo popularizado. De fato, cada objeto simples, cada lugar comum esconde dentro de sua banalidade um mundo de conhecimentos e, embora não seja trivial transformar palavras, ideias e acontecimentos não familiares em palavras e ideias usuais e acessíveis, as imagens simbólicas derivadas da ciência e que constituem o conteúdo próprio do senso comum estão sendo frequentemente reconstruídas ou retocadas.

\section{Por uma segunda ruptura: a resposta de Boaventura Santos}

A tese inicial de Santos (2004a) é que todo conhecimento científico visa a constituir-se em senso comum. Se a ciência moderna nasceu e cresceu contra o senso comum que considerou superficial, ilusório e falso, a nova ciência procura reabilitar o senso comum, reconhecendo nesta forma de conhecer algumas virtualidades fundamentais ao enriquecimento de nossa relação com o mundo. Embora reconheça o caráter conservador e mistificador desta forma de conhecimento, o autor chama a atenção para as suas potencialidades utópicas e libertárias que, em diálogo com o conhecimento científico, podem ser enriquecidas e ampliadas.

Em "Introdução a uma Ciência Pós-moderna", Santos (2003) estabelece com maior clareza o seu ponto de vista e sistematiza melhor os seus argumentos. Partindo de uma 
crítica à epistemologia bachelardiana, que considera a mais influente dos últimos anos, Santos acredita que, sendo a concepção mais avançada e que traduz, com o máximo de consciência, uma visão de ciência comprometida com a defesa da autonomia e do acesso privilegiado à verdade do conhecimento científico sem para isso recorrer a outras formas de conhecimento que não sejam da prática científica, é também a que manifesta mais claramente os limites de seus pressupostos, sendo, pois, a mais vulnerável a um processo de superação.

Ao discorrer sobre o que considera uma primeira ruptura epistemológica, Santos apresenta uma síntese do pensamento bachelardiano, particularmente no que se refere à superação do senso comum visto por aquele autor como um dos principais obstáculos epistemológicos ao desenvolvimento do conhecimento científico.

Como já discutimos a resposta bachelardiana, acrescentaremos aqui apenas os aspectos principais da crítica e da tese de Santos sobre o assunto.

Ao defender a tese de uma segunda ruptura epistemológica, Santos (2003, p.34) reconhece que a epistemologia de Bachelard interpreta fielmente o modelo de racionalidade subjacente ao paradigma da ciência moderna e o faz de maneira mais suave e mais simples que as antigas epistemologias idealistas e empiristas. No entanto, só é compreensível dentro do próprio modelo, ou seja, a ruptura epistemológica bachelardiana só é compreensível dentro do paradigma da própria ciência moderna. Assim, se o modelo em questão entra em crise, o mesmo deve suceder-se à epistemologia que lhe dá sustentação. 
Em "Um discurso sobre a ciência", Santos (2004a) procura demonstrar que a crise já se instalou e que já se encontra visível um paradigma emergente apontando para uma nova ciência que, na falta de outro nome, ele denomina de "ciência pós-moderna". De acordo com o sociólogo português, o processo histórico da crise final da ciência moderna inicia-se com a crise da epistemologia que lhe representa com maior fidelidade, isto é, a epistemologia bachelardiana. Nesse contexto, o autor aponta o reencontro da ciência com o senso comum, sugerindo uma visão alternativa que resgata os aspectos positivos dos saberes cotidianos, sobretudo o seu potencial para os projetos de emancipação social e cultural. Para Santos (2004a), justamente pelo fato de ser indisciplinar e não resultar de uma prática orientada para a produção, o senso comum é capaz de reproduzir-se espontânea e pragmaticamente sem descolar-se das trajetórias de vida dos grupos sociais. E nessa correspondência, firma-se de confiança e de segurança. Também é transparente e evidente, questionando a opacidade dos objetos tecnológicos e do obscurantismo do conhecimento científico em defesa do princípio da igualdade do acesso ao discurso e à competência cognitiva e linguística. Embora superficial quando desdenha das estruturas que estão para além das aparências, privilegiando as ações que não se descolem significativamente do real, o senso comum é exímio em captar a profundidade horizontal das relações entre pessoas e entre pessoas e coisas. Nesse sentido, é persuasivo, retórico e metafórico. Mas, conforme acredita Santos (2003), as potencialidades positivas do senso comum só conseguem se desenvolver em um contexto onde tanto ele como a ciência moderna superem a si mesmos, dando lugar a 
uma outra configuração de conhecimento. É, fundamentado nestes pressupostos, que defende a tese de uma dupla ruptura epistemológica:

Uma vez feita a ruptura epistemológica com o senso comum, o ato epistemológico mais importante é a ruptura com a ruptura epistemológica [...]. Enquanto a primeira ruptura é imprescindível para construir a ciência, mas deixa o senso comum tal como estava antes dela, a segunda ruptura transforma o senso comum com base na ciência. Com essa dupla transformação pretende-se um senso comum esclarecido e uma ciência prudente,... (p.41)

Com efeito, no contexto de uma sociedade de classes como é em geral a sociedade conformada pela ciência moderna, a vocação solidarista e transclassista do senso comum não pode escapar de assumir um viés conservador e preconceituoso que, em muitas situações reconcilia a consciência com a injustiça e transfere para o transcendente o desejo de transformação da realidade. De acordo com Santos (2003, p.37), tal argumento não permite opor a ciência ao senso comum como se opõe a luz às trevas. Primeiro porque, embora carregado de traços conservadores, o senso comum apresenta sentidos de resistência, que, dadas as condições, podem converter-se em importantes armas de luta. Depois, os mesmos traços conservadores e preconceituosos, imputados apenas ao senso comum, têm sido verificados em muitas teorias científicas que, dado o poder institucional, acabam sendo muito mais eficazes. Por fim, pode-se dizer que, do ponto de vista de 
Santos, não faz mais sentido criar um conhecimento novo e autônomo em confronto com o senso comum - primeira ruptura bachelardiana - se esse conhecimento não se destinar a transformar o senso comum e transformar-se nele, fazendo a segunda ruptura.

\section{Rupturas e continuidades: um novo senso comum para uma nova ciência}

Não é sem razão que se reúnem aqui cinco das mais importantes reflexões sobre o lugar do senso comum e da ciência na construção do tecido cultural. Certamente a problemática questão em torno da PopC\&T recupera esse debate e exige uma posição mais clara quanto à situação do conhecimento de senso comum no contexto de uma sociedade cada vez mais apoiada na ciência, na tecnologia e nos seus procedimentos muito pouco comuns.

Embora se tratando de pensadores de diferentes espaços físico-temporais, diferentes matizes ideológicas e distintas orientações disciplinares, todos eles depararam-se com o problema do senso comum em sua relação complexa com o conhecimento científico. Se, por um lado, é desaconselhável reunir pensadores de diferentes lugares ideológicos, por outro, é enriquecedor poder juntar, em um mesmo debate, pontos de vista que vão desde uma epistemologia próxima das ciências naturais (Bachelard), até o discurso da sociologia (Santos), intermediados por uma reflexão pedagógica (Freire), um olhar do marxismo moderno (Gramsci) e uma visão a partir da psicologia social (Moscovici). Todos atraídos por uma única e mesma questão: o senso comum. 
Sem dúvida, a posição bachelardiana é a mais clara e radical e, ao acreditar em Popper, a mais potencialmente falsificável. Tanto na "Filosofia do Não" como em "O Novo Espírito Científico" e, de forma ainda mais contundente, no clássico, "A Formação do Espírito Científico. Contribuição para uma Psicanálise do Conhecimento", Bachelard aponta o lugar do senso comum como um dos mais sérios obstáculos no caminho do desenvolvimento científico e, ao seguir movimento radicalizado pela ciência moderna, declara guerra ao senso comum que deve ser encarado como fonte de conservadorismos e preconceitos, tornando-se importante apenas como fator de superação.

Como já mencionamos no capítulo anterior, o desenvolvimento vitorioso das ciências naturais modernas nos séculos XIX e XX produziu uma forte influência nas ciências sociais e, particularmente, em algumas correntes marxistas que passaram a assumir posições deterministas e desconfiar dos saberes de senso comum. Impregnados de irracionalidades ideológicas, religiosas e populares, os saberes cotidianos tornavam-se sérios obstáculos a uma visão científica do ser humano, da história e da natureza, devendo ser substituídos por uma concepção materialista e marxista da realidade. Além de resgatar a importância da ideologia e aperfeiçoar o conceito de hegemonia, Gramsci afasta-se um pouco dessa corrente e, embora reconheça que o pensamento forjado, a partir das classes hegemônicas, encontra-se impregnado nos saberes cotidianos e de senso comum, ainda vislumbra um núcleo positivo de bom senso que, em contato com o conhecimento sistemático dos intelectuais organicamente comprometidos com as causas populares, pode avançar para o nível de uma consciência filosófica. 
De qualquer modo, é tarefa da filosofia da práxis superar a ideia equivocada de que o senso comum é uma filosofia original e autônoma dos grupos populares e revelar o seu caráter alienado e contraditório. A questão importante é: como essa tarefa pode ser desenvolvida? Como os ditos intelectuais orgânicos devem organizar as suas intervenções? Nesta interface, acostamo-nos ao pensamento freireano, quando se contrapõe a qualquer ação de natureza invasiva e vanguardista e defende o diálogo como única e verdadeira possibilidade de aproximação entre os saberes sistemáticos e os saberes de experiência.

Se, à maneira gramsciana, deve-se reconhecer a presença da ideologia dominante hospedada na consciência dos oprimidos, não acreditamos que a superação desse processo possa ser construída sem a participação consciente e decisiva dos próprios oprimidos. É no e pelo diálogo, que se dará o encontro emancipatório do conhecimento científico com os saberes de senso comum. E não se trata apenas de uma atitude apaixonada e respeitosa pelo conhecimento "de experiência feito" dos oprimidos, mas também, de uma atitude científica em reconhecer e valorizar um conhecimento que não pode ser desprezado, sobretudo, porque é parte da realidade cotidiana de toda nossa existência concreta no planeta.

A esse respeito, Freire coloca uma questão que merece uma reflexão mais cautelosa e demorada. Com efeito, ao discordar da ideia bachelardiana de ruptura epistemológica, impõe-nos uma pergunta de grande sutileza e profundidade: haverá ou não ruptura no processo de construção do conhecimento? Qual a diferença entre ruptura e 
superação? Seria a ciência um senso comum mais refinado e disciplinado ou um conhecimento de natureza diferente que nasce justamente a partir de uma ruptura radical com o senso comum? Aqui teremos que abrir um parêntese para, afastando-nos do problema, poder retornar a ele com maior poder de compreensão.

Retornemos então aos exemplos cunhados pelo próprio Bachelard (1984) em sua "Filosofia do Não". É a partir de uma sequência histórica envolvendo diferentes conceitos de massa que o autor demonstra os vários momentos em que se verificam as rupturas epistemológicas, isto é, a negação de um conhecimento estabelecido em benefício de uma explicação mais complexa e abrangente.

Em sua primeira forma, a ideia de massa corresponde a uma noção quantitativa grosseira e muito ligada à realidade dos sentidos. Avalia-se uma massa pelo sentido da visão, confundindo-se o maior com o mais pesado. Nesse caso, e como sempre, o primeiro conhecimento nasce com a primeira contradição: uma casca vazia contradiz as expectativas dos sentidos e impõe um rompimento com o conhecimento anterior. Um segundo nível é aquele baseado no emprego cauteloso da empiria instrumental da balança, em um exemplo clássico em que a utilização do instrumento precede a sua teoria ${ }^{47}$. Num terceiro momento, a massa é definida como um corpo de noções e não mais como um simples elemento primitivo de uma experiência imediata e direta.

47 No que se refere à antiga conceituação de massa, a balança já era utilizada muito antes do conhecimento da teoria da alavanca (BACHELARD, 1984, p.15). 
A partir de Newton (final do século XVII), a massa passou a ser definida como o quociente da força pela aceleração. Conforme Bachelard (1984), a partir do momento em que se definiram em correlação as três noções de força, de massa e de aceleração, realizou-se um imediato afastamento em relação aos princípios fundamentais do realismo empirista, podendo-se deduzir qualquer uma das noções a partir de qualquer uma das outras duas. Com efeito, partindo da escolha de três categorias fundamentais, como sejam, espaço absoluto, tempo absoluto e massa absoluta, o racionalismo newtoniano dominaria toda a física dos séculos XVIII e XIX.

Todavia, uma quarta definição de massa seria apontada pela Teoria da Relatividade (início do século XX), introduzindo uma grande abertura no racionalismo fechado em torno das concepções newtonianas e kantianas. Primeiro, a noção de massa como átomo nocional pode ser objeto de análise. Pela primeira vez, um átomo nocional pôde ser decomposto, e neste caso, chega-se a um estranho paradoxo em que o elemento, o elementar, é complexo. Por outro lado, a teoria da relatividade também revela que a massa, antes compreendida como entidade absoluta e definida no espaço e no tempo absolutos é, na verdade, uma função complicada da velocidade. A massa de um objeto, assim como o espaço e o tempo, é relativa ao deslocamento desse objeto. Portanto, numa visão bachelardiana, o racionalismo tradicional é profundamente abalado por esta noção múltipla das categorias elementares, "surgindo corpos de aproximação, corpos de explicação, corpos de racionalização". Nesse caso, uma organização é racional relativamente a um corpo de noções, não existindo uma razão absoluta. 
A quinta e última noção de massa, que aparece nos exemplos de Bachelard, é aquela sugerida por Dirac. Sem entrar em maiores detalhes sobre essa complexa construção, o autor apresenta a mecânica de Dirac como uma concepção a mais totalitária possível, do fenômeno da propagação. Com efeito, embora sob uma formulação um tanto paradoxal, a mecânica de Dirac examina em primeiro lugar a propagação dos "parênteses" num espaço de configuração, de modo que, o pensamento científico começa colocando em parêntese a própria realidade. É, portanto, "a forma de propagação que definirá em seguida aquilo que se propaga. A mecânica de Dirac é de saída, desrealizada" (BACHELARD, 1984, p.20). Todavia, o resultado de sua aplicação é ainda mais surpreendente. Além de abarcar todas as noções anteriores, os resultados encontrados por Dirac sugerem a existência de uma massa negativa. $\mathrm{Na}$ opinião de Bachelard, estamos diante de um conceito completamente inadmissível nas quatro filosofias anteriores. Com efeito, para um cientista do século XIX, o conceito de massa negativa seria mesmo um conceito monstruoso. Mas, o que tudo isso tem a ver com o senso comum?

$\mathrm{Na}$ realidade, a sequência de rupturas apresentadas na exemplificação bachelardiana revela muito mais do que uma simples negação radical de cada uma das noções anteriores. Do nosso ponto de vista, trata-se de uma situação paradoxal em que se verificam rupturas e continuidades. Senão, vejamos.

$\mathrm{Na}$ passagem da noção primitiva de massa, inicialmente confiada ao sentido da visão, para uma posterior avaliação através dos sentidos das mãos, até o uso primitivo da empiria instrumental da balança, existe um elo que, embora negue e aponte os equívocos do conhecimento 
anterior, também revela uma coerência inegável de suas escolhas. Na maioria das vezes, o fruto maior é, de fato, o mais pesado. O maior tronco tem maior massa e uma pedra pequena é mesmo mais leve que uma pedra grande. O que estamos afirmando é que a balança, embora negue algumas noções anteriores, também se encontra com elas. O mesmo ocorre com o conceito de massa sugerido pela mecânica newtoniana. A massa definida a partir da força e da aceleração encontra um elo com a massa definida a partir da empiria da balança. Embora constitua um corpo teórico bem mais abrangente, permitindo a visualização da noção de massa gravitacional, mantém um laço de vinculação com as duas noções anteriores. A massa gravitacional coincide com a massa inercial que, por sua vez, explica o sentido da balança, e esta, reencontra o sentido das avaliações primitivas do senso comum. No caso da teoria da relatividade, embora aponte para uma ruptura bem mais radical com as noções anteriores, ainda coexistem os laços de continuidade. Dessa forma, nos limites de baixas velocidades, a referida teoria reencontra a massa newtoniana, fechando novamente o elo da corrente.

Por último, para completar os exemplos em torno da construção de sua filosofia científica dispersa, Bachelard apresenta a concepção de massa em seu mais elevado nível de abstração. Trata-se da formulação da mecânica de Dirac. Surpreendentemente, mesmo naquele nível de afastamento do realismo, reencontramos uma ligação com as noções anteriores. E é o próprio Bachelard quem reconhece este fato.

Nós tínhamos apenas necessidade de uma massa; o cálculo dá-nos duas, duas massas para um só objeto. Uma dessas massas resume perfeitamente tudo o que se sabia 
da massa nas quatro filosofias precedentes: realismo ingênuo, empirismo claro, racionalismo newtoniano, racionalismo completo einsteiniano. Mas a outra massa dialética da primeira, é uma massa negativa (sic). [...] Por conseguinte, uma metade da mecânica de Dirac reencontra e continua a mecânica clássica e a mecânica relativista; a outra metade diverge numa noção fundamental; dá origem a algo diferente... (1984, p.20, os grifos em itálicos, são nossos).

De fato, encontramo-nos diante de uma questão paradoxal e é o próprio Bachelard quem reconhece a dualidade contida na complexidade dialética da noção de massa proposta por Dirac. De um lado, a ideia de uma massa negativa se constitui em uma profunda ruptura com as filosofias anteriores, de outro, a massa positiva aponta para a continuidade e o reencontro com as noções clássica e relativística. Nesse caso, trata-se de um processo complexo em que coexistem rupturas e continuidades, numa unidade hegeliana em que a cultura sempre reaparece como natureza negada, mas imediatamente reafirmada a cada nova síntese autoconsciente.

Outro contexto, não menos problemático, no qual esta questão aparece é aquele em que se discute a passagem revolucionária de uma teoria para outra em meio a uma disputa entre dois paradigmas diferentes. Em tais situações, Tomas Kuhn (2003) defende a tese da incomensurabilidade entre os diferentes paradigmas em disputa. Um exemplo típico é aquele da passagem da mecânica newtoniana para a mecânica relativista. Conforme a tese de Kuhn, embora em certas condições e limites matemáticos 
a dinâmica newtoniana possa ser aparentemente derivada da dinâmica relativista, tal derivação é espúria, pelo menos em um ponto.

... os referentes físicos desses conceitos einsteinianos não são de modo algum idênticos àqueles conceitos newtonianos que levam o mesmo nome. (A massa newtoniana é conservada; a einsteiniana é conversível com a energia. Apenas em baixas velocidades relativas podemos medi-las do mesmo modo e mesmo então não podem ser consideradas idênticas.) (KUHN, 2003, p.136).

De fato, como reconhece Kuhn, a modificação de conceitos estabelecidos e familiares é fundamental para caracterizar o impacto revolucionário da teoria de Einstein. Todavia, mesmo reinterpretada de uma maneira nova, não podemos negar o reencontro fundamental da mecânica newtoniana com a teoria da relatividade de Einstein. Neste particular, preferimos endossar a tese defendida por Bastos Filho (2005), segundo a qual, no curso de uma passagem revolucionária de uma teoria para outra, coexistem tanto aspectos de continuidade como aspectos de descontinuidade. Conforme o referido autor, no caso da teoria da relatividade, "coexistem tanto os aspectos da continuidade ensejados por um limite matemático da teoria da relatividade restrita para a mecânica newtoniana, quanto os aspectos de ruptura consubstanciados por uma descontinuidade filosófica sobre os significados dos conceitos de energia e de massa nas duas teorias" (Idem, p.67). 
Novamente sustentamos a tese de que se trata de um processo complexo em que, de fato, coexistem rupturas e continuidades. E é justamente este elo que possibilita o diálogo entre o conhecimento científico e os saberes de senso comum, dando sentido aos esforços e tentativas de popularização da ciência e tecnologia.

É só no contexto desse paradoxo que encontramos uma explicação para o conceito de superação cunhado por Freire (1996) e para a tese de uma segunda ruptura epistemológica proposta por Santos (2003). Na realidade, os dois autores tentam recuperar e manter o vínculo de ligação entre o conhecimento científico e os saberes de senso comum, flagrantemente desvinculados pela epistemologia bachelardiana. Freire o faz substituindo a palavra ruptura por superação o que, em tese, salvaria o elo da relação. No entanto, ao negar as rupturas bachelardianas corre o risco de não demarcar claramente a necessária linha divisória entre duas formas distintas de conhecimento. Santos, por sua vez, recorre a uma segunda ruptura epistemológica que considera necessária para completar o sentido da primeira. Nesse caso, uma primeira ruptura consistiria em romper com a concepção do senso comum sobre o modo como se faz ciência. De acordo com Santos (2003), essa ruptura revelaria que as diferenças entre os modos de produção do conhecimento não são tão absolutas quanto o senso comum julga, mas que, mesmo assim, existem e são significativas.

Em termos reais há, pois, um misto de cumplicidade e denúncia mútua entre as duas formas de conhecimento, e é esta ambigüidade que torna possível a segunda ruptura. Se as duas formas de conhecimento fossem 
totalmente distintas, a ciência não podia aspirar a transformar-se em senso comum, se fossem idênticas não podia pretender transformar o senso comum (SANTOS, 2003, p.50).

É interessante notar como Santos faz questão de, mantida a distinção entre o conhecimento científico e os saberes de senso comum, reconhecer a proximidade entre as duas formas de conhecer, numa formulação semelhante à nossa ideia da vinculação paradoxal entre rupturas e continuidades.

De fato, sem estes pontos de vinculação, o elo estaria quebrado e a ciência se afastaria completamente da comunidade de sentidos, tornando-se uma entidade estranha à ideia de pertencimento à humanidade. Pelo menos por enquanto, ainda não identificamos tal processo. Se esta será uma possibilidade futura, não se pode desdenhar e isso nos remete a uma das cenas finais do filme "Inteligência Artificial" ${ }^{48}$.

Depois de perdido o elo com as suas origens (humana), uma civilização estranha consegue reencontrar o elo perdido com os seus ancestrais através da leitura dos chips da memória de um pequeno robô resgatado como relíquia perdida no fundo do mar. A história do homem é recuperada apenas através de sua memória projetada em uma

48 Um filme de Stanley Kubrick, dirigido por Stephen Spielberg que não chegou a ser um trabalho a quatro mãos porque Kubrick morreu antes do início da produção. Contudo, AI, Inteligência Artificial guarda as características da visão sombria de Kubrick com o sentimentalismo de Spielberg. Como o próprio título sugere, o filme trata da inteligência artificial em um mundo futuro em que homens e máquinas se confundem até nos sentimentos. 
máquina. Se esta imagem poética produzida pela ficção científica encontrar a realidade nos limites de uma não muito longínqua sociedade pós-humana, não nos cabe prognosticar aqui. Por enquanto ainda somos comuns, ainda somos materiais, organismos vivos existenciais e enraizados no mundo e quase toda essa existência se sustenta no conhecimento do senso comum. A esse respeito é muito oportuna a fala de Nietzsche no seu fragmento 111 sobre a origem da lógica.

Quem, por exemplo, não sabia descobrir o "igual" com suficiente freqüência, no tocante à alimentação ou no tocante aos animais que lhe eram hostis, quem portanto subsumia demasiado lentamente, era demasiado cauteloso na subsunção, tinha menor probabilidade de sobrevivência do que aquele que em todo semelhante adivinha logo a igualdade [...] - foi preciso que por longo tempo o mutável nas coisas não fosse visto, não fosse sentido; os seres que não viam com precisão tinham uma vantagem diante daqueles que viam tudo "em fluxo" (NIETZSCHE, 1983, p.201).

Assim como a ciência, o senso comum se desenvolve como uma forma peculiar de reducionismo. Enquanto a ciência tornou-se especialista no que se refere às estruturas que estão para além dos sentidos e das aparências, $o$ senso comum é exímio em captar a profundidade horizontal das coisas, fornecendo generalizações imediatas e fundamentais para o movimento e sobrevivência da espécie. 
Nesse caso, concordamos com Moscovici (2003) quando afirma que o conhecimento de senso comum não pode ser considerado distorcido e errado como sempre se supôs. Na verdade, ele se enquadra perfeitamente aos propósitos e necessidades da vida cotidiana, chegando mesmo a encantá-la e torná-la digna de ser vivida durante muitos séculos. Mais do que isso, como reconhece Koyré, muitos princípios científicos encontram seus pontos de partida nas intuições do senso comum.

... quando a termodinâmica afirma à laia de princípio, que o calor não passa de um corpo frio para um corpo quente, faz ela outra coisa que não seja transpor uma intuição do senso comum, segundo a qual um corpo quente arrefece "naturalmente", enquanto um corpo frio "naturalmente" não aquece? E mesmo quando dizemos que o centro de gravidade de um sistema tende a tomar a posição mais baixa e não torna a subir por si mesmo, não é isso ainda uma transposição da intuição fundamental do senso comum...? (1992, p.22)

Mesmo na mais radical das revoluções científicas contra o senso comum, qual seja, na retirada da terra do seu estado comum de repouso para colocá-la em movimento circular ao redor do Sol; mesmo nesse caso, as evidências de senso comum não podem ser desdenhadas, pois, de fato, considerando-se um sistema de referência fixo na terra, como é o caso, as observações e conclusões construídas a partir de imagens do senso comum, recuperam sentido e não podem ser consideradas absurdas. 
Por outro lado, como qualquer outra forma de conhecimento, o conhecimento de senso comum também está em contínua transformação, sendo permanentemente criado e recriado, sobretudo, em sociedades onde se verifica uma maior popularização do conhecimento científico e tecnológico. De fato, muitos conhecimentos dantes revolucionários, tais como, a ideia de que a terra se move em torno do Sol ou a propagação de ondas eletromagnéticas, acabaram por ser incorporados ao cotidiano, tornando-se ideias comuns.

... as imagens simbólicas derivadas da ciência em que ele está baseado e que, enraizadas no olho da mente, conformam a linguagem e o comportamento usual, estão constantemente sendo retocadas. No processo, a estocagem de representações sociais, sem a qual a sociedade não pode se comunicar ou se relacionar e definir a realidade, é realimentada (MOSCOVICI, 2003, p.95).

Decerto, não explicamos mais a realidade a partir de nossas simples e precárias representações mentais, mas, como sugere Omnès (1996, p.193), são essas representações, com a intuição e o senso comum que as acompanha, que queremos explicar a partir do conhecimento das leis do universo a que o conjunto do pensamento científico nos levou. Conhecer o conhecimento e pensar o pensamento para entender suas limitações e possibilidades, tornou-se possível. Surpreendentemente, essa compreensão mais profunda de nosso pensar revelou os limites, mas, sobretudo, a importância do conhecimento de senso comum, do qual jamais podemos, de todo, escapar. Foi necessário o profundo afastamento formal produzido pela mecânica 
quântica para reconhecermos que a singularidade do ser humano e a sua estranha consciência da realidade não podem ser reduzidas aos simples conceitos de partículas elementares e campos. "É como se homem e mulher se tivessem lançado na aventura de conhecer os objetos mais distantes e diferentes de si próprios, para, uma vez aí chegados, se descobrirem refletidos como num espelho" (SANTOS, 2004a, p.62).

Como nos lembra Lévy-Leblond (2004), por mais que a ciência seja formalizada, ela não pode prescindir da linguagem comum. É no espaço entreaberto para sempre entre o cálculo e a palavra que o pensamento pode se manifestar, tanto por meio da narração e da metáfora, como por intermédio do imaginário. Se for, de fato, objetivo da ciência proceder à crítica do senso comum, para alcançar tal intento, é fundamental inserir-se na comunidade de sentidos, sem qualquer privilégio de exceção linguística.

Ademais, é preciso compreender, antes de tudo que, nenhuma forma de conhecimento isolada é por si mesma racional e só a conjunção de todos os esforços nos permite conhecer melhor. De fato, parece que, como já sugeria William James em 1906, "o senso comum é melhor para uma esfera da vida, a ciência para outra e a crítica filosófica para uma terceira: mas só Deus sabe qual deles é, em termos absolutos, mais verdadeiro (apud SANTOS, 2003, p.48).

Nesse sentido, buscar o diálogo com outras formas de conhecimento é uma atitude mais fecunda e reconhecidamente aceita pela nova visão de ciência que desponta no início do século XXI. E, sem dúvida, o conhecimento do senso comum; aquele "de experiência feito" e que orienta todas as nossas ações cotidianas é a mais importante 
de todas estas formas. De fato, como escreve Santos, "A ciência moderna construiu-se contra o senso comum que considerou superficial, ilusório e falso. A ciência pós-moderna ${ }^{49}$ procura reabilitar o senso comum por reconhecer nesta forma de conhecimento algumas virtualidades para enriquecer a nossa relação com o mundo" (2004a, p.88).

Portanto, não faz mais sentido criar um conhecimento novo e autônomo em confronto com o senso comum, se esse conhecimento não se destinar a transformar o senso comum e transformar-se nele. Se o discurso científico tem se tornado cada vez mais um discurso anormal e incomensurável com os discursos normais que circulam na cotidianidade das práticas sociais. Se o distanciamento e a estranheza deste discurso em relação aos discursos ético, estético, religioso e do senso comum constituem o cerne da ciência moderna, se considerados os altos níveis de especialização, esta estranheza já se reproduz no próprio interior da comunidade científica, haveremos que, seguindo Santos (2003, p.13), proceder a uma ruptura da ruptura e, à busca do diálogo, estabelecer uma atitude permanentemente hermenêutica que tenta transformar a ciência, de um objeto estranho, distante e incomensurável, num objeto familiar e próximo que, embora não compartilhe a língua de todos os dias, é capaz de comunicar os seus feitos, como também, os seus limites. Trazer o Golem ${ }^{50}$ para o interior da casa, para a familiaridade, é o único caminho que nos resta.

49 Em duas obras mais recentes, Santos define o novo paradigma não mais como ciência pós-moderna, mas como o paradigma de um conhecimento prudente para uma vida decente, (Santos, 2005, 2006).

50 Criatura da mitologia judaica que, feito de argila e água, depois de certos encantamentos, assume a forma de um humanóide. 